\title{
Comparison of Lettuce Diseases and Yield Under Subsurface Drip and Furrow Irrigation
}

\author{
K. V. Subbarao, J. C. Hubbard, and K. F. Schulbach
}

First and second authors: Department of Plant Pathology, University of California, Davis, c/o U.S. Agricultural Research Station, 1636 E. Alisal St., Salinas 93905; third author: University of California Cooperative Extension, 1432 Abbott Street, Salinas 93901. Accepted for publication 9 May 1997.

\begin{abstract}
Subbarao, K. V., Hubbard, J. C., and Schulbach, K. F. 1997. Comparison of lettuce diseases and yield under subsurface drip and furrow irrigation. Phytopathology 87:877-883.

Subsurface drip and furrow irrigation were compared on lettuce ( $\mathrm{Lac}$ tuca sativa) cvs. Salinas and Misty Day for yield and incidence and severity of three important diseases of lettuce in the Salinas Valley, CA. Experiments were conducted between 1993 and 1995 during the spring and fall seasons. The diseases examined included lettuce drop (Sclerotinia minor), downy mildew (Bremia lactucae), and corky root (Rhizomonas suberifaciens). Replicated plots of subsurface drip and furrow irrigation were arranged in a randomized complete-block design. All plants were inoculated with $S$. minor at the initiation of the experiment during the 1993 spring season. Plots were not inoculated for downy mildew and corky root during any season nor were the plots reinoculated with $S$. minor. During each season, all plots were sprinkler irrigated until thinning, and subsequently, the irrigation treatments were begun. The furrow

plots were irrigated once per week, and the drip plots received water twice per week. The distribution of soil moisture at two soil depths ( 0 to 5 and 6 to $15 \mathrm{~cm}$ ) at 5,10 , and $15 \mathrm{~cm}$ distance on either side of the bed center in two diagonal directions was significantly lower in drip-irrigated compared with furrow-irrigated plots. Plots were evaluated for lettuce drop incidence and downy mildew incidence and severity at weekly intervals until harvest. Corky root severity and yield components were determined at maturity. Lettuce drop incidence and corky root severity were significantly lower and yields were higher in plots under subsurface drip irrigation compared with furrow irrigation, regardless of the cultivar, except during the 1994 fall season. Incidence and severity of downy mildew were not significantly different between the two irrigation methods throughout the study. The differential microclimates created by the two irrigation treatments did not affect downy mildew infection, presumably because the mesoclimate is usually favorable in the Salinas Valley. Subsurface drip irrigation is a viable, long-term strategy for soilborne disease management in lettuce in the Salinas Valley.
\end{abstract}

Lettuce drop is an important disease throughout the lettuce ( $L a c$ tuca sativa $\mathrm{L}$ ) producing states in the United States and other parts of the world $(3,14,18)$. Lettuce drop is caused by two species of Sclerotinia, S. sclerotiorum (Lib.) de Bary and S. minor Jagger. In the coastal valleys of California, lettuce drop is caused predominantly by $S$. minor (18). Regardless of the species causing the disease, lettuce drop symptoms include a soft, watery crown and root rot of both head and leaf lettuce. The disease can occur at any stage of crop growth but predominantly occurs near harvest (3).

$S$. minor survives in soil as sclerotia. Unlike those of S. sclerotiorum, the sclerotia seldom produce apothecia, and all infections, therefore, are caused by direct germination of sclerotia. Under optimum moisture conditions $(1,3,12)$, sclerotia germinate eruptively, producing masses of hyphae that come in contact with roots, stems, and senescent leaves, causing soft, watery crown and root rot $(4,18,19)$. Large numbers of sclerotia are produced in colonized lettuce tissues. The majority of lettuce drop infections are caused by $S$. minor sclerotia in the top $8 \mathrm{~cm}$ of soil, located about $2 \mathrm{~cm}$ from the crowns, which is defined as the competence zone or volume of soil encompassing the maximum distance and depth from which a sclerotium can cause infection (9). A single viable sclerotium within the competence zone can cause infection, but a good correlation between sclerotial density of more than 7 sclerotia per $100 \mathrm{~g}$ of soil and disease incidence has been documented (7).

Survival of $S$. minor sclerotia for less than 1 month to nearly 11 years has been recorded under varying soil conditions $(1,3,8,11)$. Survival is affected primarily by soil moisture and burial depth

Corresponding author: K. V. Subbarao; E-mail address: kvsubbarao@ucdavis.edu

Publication no. P-1997-0624-01R

(C) 1997 The American Phytopathological Society
$(2,12)$. Sclerotia either disintegrate or fail to germinate in saturated soils and survive better in soils with fluctuating moisture $(2$, 12 ), but their germination decreases progressively with time and burial depth (11). Sclerotia germinate poorly soon after production on host tissues because of the high innate moisture content and have to dry first before a majority of them can rehydrate and germinate (19).

Corky root of lettuce, caused by Rhizomonas suberifaciens (24), has become increasingly important in the Salinas and Santa Maria valleys of coastal California during recent years. The disease occurs on various soil types, ranging from sandy loam to clay. Early symptoms consist of banded yellow areas on the taproot, while the internal tissues are still healthy. The taproot and main lateral roots progressively become very rough (corky), dark greenish-brown, and brittle. Taproots are shortened substantially, and lateral roots may be few or nonexistent. Severely infected plants remain undersized and often are too small to be harvested.

Downy mildew of lettuce, caused by Bremia lactucae Regel, is the most important disease of lettuce in California. Downy mildew begins as small, chlorotic lesions on leaves that turn yellow and necrotic after sporulation. The lesions are angular, variable in size, and often delineated by large veins. Under prolonged morning leaf wetness conditions (22), existing lesions can ramify quickly to cover most of the leaves, or new lesions can occur. Severe infections render the crop unmarketable.

The occurrence and severity of both lettuce drop and corky root are influenced by moisture-related environmental and management factors $(1,2,12,23)$. The relative merits of different irrigation methods to manage this disease are largely unknown. In recent years, increasing numbers of growers in the Salinas Valley have begun installing subsurface drip-irrigation systems, primarily because of benefits such as reduced requirements of nitrogen and 
water. Compared with overhead sprinkler- or furrow-irrigation systems, the subsurface drip-irrigation system is more efficient, provides incremental and steady application of nitrogen and water, and reduces drainage and corresponding $\mathrm{NO}_{3}{ }^{-}$leaching. The subsurface drip-irrigation system, however, is very expensive, requires intensive management, is long-term, and is not easily replaceable. Before a large-scale switch to this irrigation technology occurs in lettuce production, it is important to determine the merits and risks of the system for management of lettuce diseases.

The objectives of this study were to determine the development of lettuce drop and the relative yield under furrow and subsurface drip irrigation; to compare incidence and severity of two other important lettuce diseases, corky root caused by $R$. suberifaciens and downy mildew caused by $B$. lactucae, under the two irrigation systems; to compare the efficacy of fungicides for lettuce drop control under the two irrigation systems; and to elucidate the possible mechanisms of irrigation-mediated disease suppression.

\section{MATERIALS AND METHODS}

Experimental site. The experiments were conducted at Hartnell East Campus in Salinas, CA. The soil is an Antioch fine sandy loam (45\% sand, $32 \%$ silt, $23 \%$ clay, and $2.2 \%$ organic matter). From previous studies conducted over the years, it had been determined that sclerotial populations of $S$. minor in soil at this site were low, and as a result, the incidence of lettuce drop was negligible. Inoculation of lettuce plants, therefore, was necessary not only to ensure the availability of inoculum but also its uniformity across the plots. Plants were inoculated only once during the 1993 spring season experiment (first lettuce crop). Previous studies also had revealed that the incidence and severity of corky root on lettuce was very high, especially on the fall crop of lettuce, and no inoculations or soil infestation with this pathogen were necessary.

Plot establishment. The irrigation treatments in the experiment included furrow and subsurface drip irrigation and were arranged in a randomized complete-block design with three replications. Individual plots were 6 beds wide and $25 \mathrm{~m}$ long with $1 \mathrm{~m}$ between bed centers. To prevent edge effects, the plots were separated by a border row that belonged to neither type of irrigation. In plots with subsurface drip irrigation, a single drip-irrigation line $(0.5-\mathrm{mm}$ plastic drip tape) (T-Systems International, San Diego, CA) with emitters spaced $20 \mathrm{~cm}$ apart was buried $25 \mathrm{~cm}$ below the soil surface in the middle of the raised beds prior to planting of the first lettuce crop. These feeder tapes were connected to a main line that in turn was connected to the source of the water supply. The drip tape remained in the soil for the duration of the study.

During the spring and fall seasons of each year, lettuce cvs. Salinas and Misty Day, respectively, were direct seeded in two rows on each bed. Fertilization of the plots during each crop cycle was done by "best management practices" (5), i.e., <160 kg of $\mathrm{N}$ per ha, with banded, split applications. Soon after planting, all plots were irrigated with sprinklers to facilitate uniform emergence of the lettuce seedlings. Sprinkler irrigation was continued until thinning. Three weeks after emergence, the lettuce seedlings in both rows within a bed were thinned to a spacing of $30 \mathrm{~cm}$.

Implicit also in this study was the evaluation of the corresponding tillage treatments in the two irrigation methods (K. V. Subbarao, unpublished data). After crop harvest each season, the mandatory minimum tillage treatment in the subsurface drip-irrigated plots and the conventional tillage treatment in the furrow-irrigated plots were introduced. Plot preparation procedures recommended for the subsequent crop in the two irrigation treatments were followed.

Inoculum production and inoculation. Aliquots of $20 \mathrm{~g}$ of rye seed and $10 \mathrm{ml}$ of distilled water were dispensed into 125-ml Erlenmeyer flasks and autoclaved twice at $121^{\circ} \mathrm{C}$ for $1 \mathrm{~h}$ each time. A monosclerotial isolate of $S$. minor from a commercial lettuce production field in Salinas was plated on potato dextrose agar medium at room temperature $\left(23 \pm 2^{\circ} \mathrm{C}\right)$. After 2 days of incubation, two 4-mm-diameter mycelial plugs from the edge of this culture were dispensed into each of the above conical flasks containing rye seed and incubated on laboratory benches for 3 weeks. After 1 week of incubation, the conical flasks were shaken to facilitate maximal colonization of rye seeds by the pathogen.

After 3 weeks of incubation, the rye kernels, as well as the associated mycelium and sclerotia, were used as inoculum. In 1993, every plant in the experiment (nearly 6,000 total) was inoculated individually by placing one or two rye kernels on the soil surface $\sim 1 \mathrm{~cm}$ from the crown of 1-month-old lettuce plants ( 1 week after thinning).

Irrigation. Irrigation treatments were begun immediately after inoculation during the 1993 spring season and immediately after thinning during the subsequent seasons. The frequency of irrigation was determined by the evapotranspiration rates for the Salinas Valley and the crop coefficients for lettuce (5). Based on these two variables, the subsurface drip plots were irrigated twice during the week (drip tapes were pressurized at $0.56 \mathrm{~kg} / \mathrm{cm}^{2}$ at 9:00 a.m., and irrigation was terminated at 3:00 p.m. on each day), and the furrow plots were irrigated once during the week (begun at 9:00 a.m. and continued until the furrows were three-fourths full).

In the 1995 spring and fall lettuce crops, lettuce drop development was compared under fungicide-sprayed and unsprayed conditions under both subsurface drip and furrow irrigations. The two outside rows of each plot were sprayed with iprodione (Rovral 4F) at a rate of $2.24 \mathrm{~kg} / \mathrm{ha}$ immediately after thinning during both seasons. Lettuce drop incidence in fungicide-sprayed and unsprayed plots was determined as described below.

To determine the distribution of soil moisture across the beds under the two irrigation methods, gypsum blocks (Soil Moisture Equipment Co., Santa Barbara, CA) were buried at 2, 4, and $6 \mathrm{~cm}$ distances on either side of the bed center at depths of 5 and $15 \mathrm{~cm}$ at one location near the center of each plot. The resistance of the gypsum blocks was recorded weekly 2 days after both irrigation events occurred with the resistance device supplied by the manufacturer. The electrical resistance readings were converted to megapascals based on the charts provided by the manufacturer. Soil temperatures also were recorded at depths of 5 and $15 \mathrm{~cm}$ with a soil temperature probe attached to a $21 \mathrm{X}$ datalogger (Campbell Scientific, Logan, UT).

Data collection. The plots were monitored weekly for the onset of lettuce drop and downy mildew. After the initial appearance of lettuce drop, the total plants in the middle four rows of the plots and the number exhibiting lettuce drop symptoms were recorded weekly until harvest. Similarly, the total number of plants and the number with lettuce drop symptoms were recorded on fungicidesprayed rows separately in 1995.

At the same time, the total number of plants and the number with downy mildew symptoms from six randomly chosen 1-m sections of each plot were evaluated. The severity of downy mildew infection was rated, using a scale based on the marketability of lettuce heads: $1=<5 \%$ of exposed leaf area covered by lesions, lesions very small and few, removal of infected leaves would not affect plant quality; $2=5$ to $9 \%$ of exposed leaf area covered by lesions, lesions of moderate size and many small lesions, removal of infected leaves would marginally affect quality; $3=10$ to $14 \%$ of exposed leaf area covered by lesions, removal of infected leaves would markedly affect quality; and $4=\geq 15 \%$ of exposed leaf area covered by lesions, large diffuse lesions or many large discrete lesions, unmarketable.

At harvest, an area $6 \mathrm{~m}$ long and 4 beds wide was demarcated in the center of each plot for collecting yield and disease data. The total number of plants and the number exhibiting lettuce drop symptoms in this area were counted. Ten lettuce plants were uprooted randomly with intact taproots from each plot, and corky root severity was determined by the scale of O'Brien and van Bruggen (17). In addition, all marketable heads were harvested and counted, 
and the total trimmed weights was determined for each plot. Ten of these heads were chosen randomly, and the volume of the heads was determined as described previously (17).

Data analysis. The incidence of lettuce drop and downy mildew under the two types of irrigation was calculated. Disease progress curves were generated for both diseases for each season. Repeated-measures analysis of variance (ANOVA) was conducted on downy mildew severity to determine whether there were treatment differences and to determine time interactions.

Based on the biology of the pathogen, monomolecular transformation (6) of disease proportions was deemed appropriate, and infection rates were calculated for each type of irrigation for each season by regression analysis of the transformed disease proportions (adjusted for asymptotes) on time (6). The rates of disease progress under subsurface drip and furrow irrigation were compared by a $t$ test $(P=0.05)$.

Yield variables (number of marketable heads, proportion of marketable heads in total number of plants, volume of lettuce heads, and overall yield), lettuce drop incidence, and corky root severity at harvest were analyzed separately for each season because over- all yields were significantly different between seasons. ANOVA was performed to determine the effects of irrigation methods, and treatment means were compared by an LSD test $(P \leq 0.05)$. To determine whether there was any year-treatment interaction, data for each cultivar over the corresponding years were analyzed together by ANOVA.

\section{RESULTS}

Lettuce drop progress. The progress of lettuce drop under the two irrigation treatments and the cultivar responses were similar during each season. Lettuce drop incidence was not different between furrow- and subsurface drip-irrigation treatments during the first 2 weeks after the irrigation treatments were begun. Subsequently, the treatments began to differentiate, and consistently, the incidence of lettuce drop was significantly lower in the subsurface drip-irrigated plots (Fig. 1). During the 1994 fall season, however, unseasonable rains 2 weeks prior to the harvest narrowed the differences between furrow- and subsurface drip-irrigated plots, although final drop incidence was significantly different (Fig. 1).
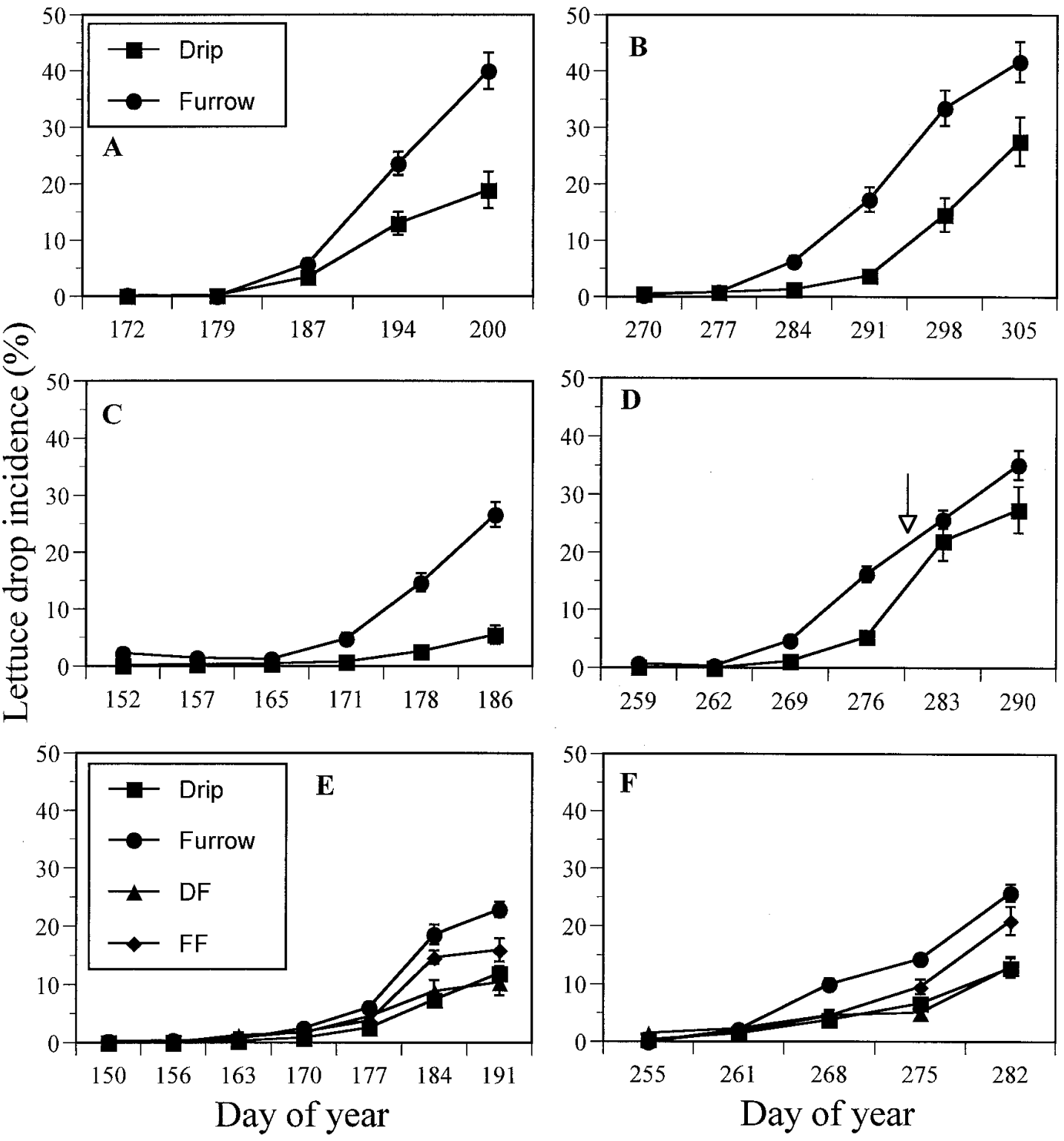

Fig. 1. Progress of lettuce drop in subsurface drip- and furrow-irrigation treatments during $\mathbf{A}, \mathbf{C}$, and $\mathbf{E}$, the spring seasons; and $\mathbf{B}, \mathbf{D}$, and $\mathbf{F}$, the fall seasons of 1993 to 1995 . Lettuce cvs. Salinas and Misty Day were planted during the spring and fall seasons each year, respectively. The arrow in $\mathbf{D}$ indicates the date when unseasonable rains began. Vertical bars indicate the standard errors of the mean. During both the spring $(\mathbf{E})$ and fall $(\mathbf{F})$ of 1995 , lettuce drop progress also was evaluated in the fungicide-sprayed portion of the subsurface drip (DF) and furrow (FF) irrigated plots. 
Lettuce drop incidence was highest in furrow-irrigated plots during the 1993 spring season, when every plant in the experiment was inoculated, and in the subsequent crop during the 1993 fall season (41.8 and 59.8\%, respectively). During the remaining four seasons, the incidence varied between 20 and $35 \%$ in the furrowirrigated plots (Fig. 1). In the subsurface drip-irrigated plots, the highest lettuce drop incidence when no rainfall occurred during the study (31.4\%) was recorded during the fall of 1993. During all other seasons when no rainfall occurred, the incidence under subsurface drip irrigation was less than $20 \%$ (Fig. 1). Unseasonable rains during the 1994 fall season interfered with the irrigation treatments, and the highest level of lettuce drop incidence under subsurface drip irrigation was recorded in this season.

Comparison of lettuce drop incidence in fungicide-sprayed and unsprayed lettuce during both the spring and fall of 1995 provided differential results under the two irrigation methods. During both seasons, incidence of lettuce drop was significantly lower in fun-

TABLE 1. Infection rates (monomolecular model) for lettuce drop progress caused by Sclerotinia minor under subsurface drip- and furrow-irrigation systems during the spring and fall lettuce crop seasons of 1993 to 1995 in the Salinas Valley, CA

\begin{tabular}{lllcc}
\hline $\begin{array}{l}\text { Year and } \\
\text { season }\end{array}$ & Cultivar & Irrigation & $r_{\mathrm{M}} \pm \mathrm{SE}^{\mathrm{y}}$ & $R_{\mathrm{adj}^{\mathrm{z}}}$ \\
\hline 1993 spring & \multirow{2}{*}{ Salinas } & Drip & $0.0139 \pm 0.003$ & 0.56 \\
& & Furrow & $0.0278 \pm 0.005$ & 0.59 \\
1993 fall & \multirow{2}{*}{ Misty Day } & Drip & $0.0142 \pm 0.003$ & 0.52 \\
& & Furrow & $0.0327 \pm 0.006$ & 0.55 \\
1994 spring & \multirow{2}{*}{ Salinas } & Drip & $0.0039 \pm 0.001$ & 0.43 \\
& & Furrow & $0.0106 \pm 0.002$ & 0.61 \\
& \multirow{2}{*}{ Misty Day fall } & Drip & $0.0178 \pm 0.004$ & 0.59 \\
& & Furrow & $0.0232 \pm 0.002$ & 0.86 \\
& \multirow{2}{*}{ Salinas } & Drip & $0.0043 \pm 0.001$ & 0.73 \\
& & Drip + fungicide & $0.0042 \pm 0.001$ & 0.68 \\
1995 fall & \multirow{2}{*}{ Misty Day } & Furrow & $0.0100 \pm 0.001$ & 0.74 \\
& & Furrow + fungicide & $0.0067 \pm 0.001$ & 0.73 \\
& & Drip + fungicide & $0.0071 \pm 0.001$ & 0.82 \\
& & Furrow & $0.0068 \pm 0.002$ & 0.74 \\
& & Furrow + fungicide & $0.0166 \pm 0.002$ & 0.85 \\
& & & $0.0115 \pm 0.002$ & 0.71 \\
\hline
\end{tabular}

y Infection rates were calculated after adjusting for asymptotes plus/minus standard error. Differences in infection rates between subsurface drip and furrow irrigation were significant for each season according to a $t$ test $(P<0.05)$, as were the rates between fungicide-sprayed and unsprayed plots within furrow irrigation during the spring of 1995.

${ }^{\mathrm{z}}$ Coefficient of determination adjusted for $\mathrm{df}$. gicide-sprayed lettuce compared with unsprayed lettuce under furrow irrigation (Fig. 1E and F). In contrast, neither the final incidence nor the disease progress could be differentiated between fungicide-sprayed or unsprayed lettuce under subsurface drip irrigation (Fig. 1E and F).

Examination of the taproots of infected plants from the two irrigations also revealed differences. The taproots of infected plants from plots irrigated by furrow were completely colonized by $S$. minor mycelium, and both the aboveground crown and lower leaves and belowground taproot were modified into sclerotia. In contrast, the colonization of taproots of infected plants from subsurface drip-irrigated plots was incomplete and restricted to less than $2 \mathrm{~cm}$ below the ground. The formation of sclerotia also was restricted to the crown.

No plant-to-plant spread of lettuce drop or production of infective secondary inoculum was observed in either cultivar anytime during the study. Rates of infection under the two irrigation methods followed trends similar to disease incidence. During each season, the rates of disease progress were significantly higher in plots irrigated by furrow than in those irrigated by subsurface drip. The rates varied between 0.01 and 0.03 day $^{-1}$ under furrow irrigation and between 0.004 and 0.01 day $^{-1}$ under subsurface drip irrigation (Table 1).

Corky root. Because the soil had high $R$. suberifaciens population densities and corky root was more severe on the fall crop than on other crops, the corky root-resistant cv. Misty Day had to be planted during the fall each year to have sufficiently healthy plants to collect data on all other variables. Therefore, the effects of the two irrigation methods on corky root severity in lettuce could be evaluated only on the spring crop. Each spring, corky root severity on the susceptible cv. Salinas was significantly lower on plants from the subsurface drip-irrigated plots than on plants from furrow-irrigated plots (Table 2). Subsurface drip irrigation alone reduced corky root severity by more than $50 \%$ in two of the three seasons and by nearly $50 \%$ in the other season. Corky root data on cv. Misty Day were collected during the fall, but significant differences between the irrigation methods was observed on this cultivar in only one season (Table 2).

Lettuce downy mildew. Incidence and severity of lettuce downy mildew were variable during different seasons. ANOVA indicated that no significant differences in the incidence or severity of downy mildew existed between the two irrigation treatments. Even though significant differences in downy mildew incidence between furrowand drip-irrigated plots were observed on some disease-assess-

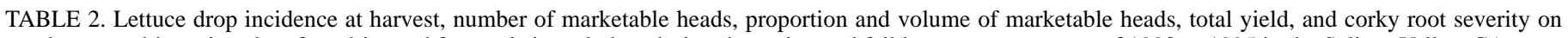
two lettuce cultivars in subsurface drip- and furrow-irrigated plots during the spring and fall lettuce crop seasons of 1993 to 1995 in the Salinas Valley, CA

\begin{tabular}{|c|c|c|c|c|c|c|c|c|}
\hline Year and season & Cultivar & Irrigation & Drop $^{\text {s }}(\%)$ & $\mathrm{NMH}^{\mathrm{t}}$ & $\begin{array}{c}\text { Proportion } \\
\text { of heads }\end{array}$ & $\begin{array}{c}\text { Volume of } \\
\text { heads }\left(\mathrm{cm}^{3}\right)^{\mathrm{v}}\end{array}$ & Yield $(\mathrm{kg})^{\mathrm{w}}$ & $\mathrm{CR}^{\mathrm{x}}$ \\
\hline \multirow[t]{2}{*}{1993 spring } & \multirow[t]{2}{*}{ Salinas } & Drip & $21.6 b^{y}$ & $28.8 \mathrm{a}$ & $67.2 \mathrm{a}$ & 969 a & $15.7 \mathrm{a}$ & $3.8 \mathrm{~b}$ \\
\hline & & Furrow & $41.8 \mathrm{a}$ & $21.2 \mathrm{~b}$ & $52.1 \mathrm{~b}$ & $580 \mathrm{~b}$ & $9.5 \mathrm{~b}$ & $8.9 \mathrm{a}$ \\
\hline \multirow[t]{2}{*}{1993 fall } & \multirow[t]{2}{*}{ Misty Day } & Drip & $31.4 \mathrm{~b}$ & $22.3 \mathrm{a}$ & $53.1 \mathrm{a}$ & $940 \mathrm{a}$ & $10.1 \mathrm{a}$ & $3.8 \mathrm{a}$ \\
\hline & & Furrow & $59.8 \mathrm{a}$ & $13.6 \mathrm{~b}$ & $32.2 \mathrm{~b}$ & 948 a & $6.7 \mathrm{~b}$ & $4.5 \mathrm{a}$ \\
\hline \multirow[t]{2}{*}{1994 spring } & \multirow[t]{2}{*}{ Salinas } & Drip & $3.3 \mathrm{~b}$ & $38.3 \mathrm{a}$ & $70.2 \mathrm{a}$ & 802 a & $21.9 \mathrm{a}$ & $3.3 \mathrm{~b}$ \\
\hline & & Furrow & $33.8 \mathrm{a}$ & $24.3 \mathrm{~b}$ & $42.2 \mathrm{~b}$ & $680 \mathrm{~b}$ & $14.1 \mathrm{~b}$ & $9.4 \mathrm{a}$ \\
\hline \multirow[t]{2}{*}{1994 fall } & \multirow[t]{2}{*}{ Misty Day } & Drip & $\ldots^{\mathrm{z}}$ & $\ldots$ & $\ldots$ & $\ldots$ & $\ldots$ & $\ldots$ \\
\hline & & Furrow & $\ldots$ & $\ldots$ & $\ldots$ & $\ldots$ & $\ldots$ & $\ldots$ \\
\hline \multirow[t]{2}{*}{1995 spring } & \multirow[t]{2}{*}{ Salinas } & Drip & $10.3 \mathrm{~b}$ & $42.3 \mathrm{a}$ & $85.3 \mathrm{a}$ & $1,516 \mathrm{a}$ & $31.0 \mathrm{a}$ & $4.4 \mathrm{~b}$ \\
\hline & & Furrow & $27.4 \mathrm{a}$ & $37.8 \mathrm{~b}$ & $73.5 \mathrm{~b}$ & $1,011 \mathrm{~b}$ & $25.0 \mathrm{~b}$ & $7.2 \mathrm{a}$ \\
\hline \multirow[t]{2}{*}{1995 fall } & \multirow[t]{2}{*}{ Misty Day } & Drip & $15.1 \mathrm{~b}$ & $19.0 \mathrm{a}$ & $48.5 \mathrm{a}$ & $1,218 \mathrm{a}$ & $9.4 \mathrm{a}$ & $2.6 \mathrm{~b}$ \\
\hline & & Furrow & $41.8 \mathrm{a}$ & $8.7 \mathrm{~b}$ & $24.8 \mathrm{~b}$ & $1,167 \mathrm{a}$ & $4.1 \mathrm{~b}$ & $3.1 \mathrm{a}$ \\
\hline
\end{tabular}

${ }^{\mathrm{s}}$ Mean lettuce drop incidence in the central 24- $\mathrm{m}^{2}$ area of the middle four beds of each treatment plot.

${ }^{t}$ Mean number of marketable lettuce heads in the central $24-\mathrm{m}^{2}$ area of the middle four beds of each treatment plot.

u Mean of the ratio of the number of marketable heads to the total number of lettuce plants in the 24- $\mathrm{m}^{2}$ area.

v Mean volume of lettuce heads.

${ }^{w}$ Mean weight of the total marketable heads.

x Mean corky root severity estimated by the scale of O'Brien and van Bruggen (17).

y Within each column and season, numbers followed by the same letter are not significantly $(P>0.05)$ different according to an LSD test.

${ }^{\mathrm{z}}$ Crop not harvested. 
ment dates within a season, the overall differences were neither obvious nor significant (Fig. 2).

Lettuce yield. The effects of the two irrigation methods on all yield variables measured were consistent regardless of the cultivars and year $(P>0.65$ for year-treatment interaction). The treatments also were significantly different for each of the variables measured. The magnitude of differences between the two irrigation treatments was not identical between the seasons, however. The lettuce drop incidence in the plot area where yield data were collected was significantly lower in the subsurface drip-irrigated plots than in furrow-irrigated plots for both cultivars (Table 2). Proportionally, the number of harvestable plants was significantly higher under subsurface drip irrigation, as were the number of marketable heads and the overall yield during each season regardless of the cultivar. The volume of lettuce heads was significantly different between the irrigation treatments only for cv. Salinas (Table 2).

Soil moisture distribution and temperature. Significantly different patterns of soil moisture distribution in the planting beds were observed under the two irrigation systems. Under furrow irrigation, 2 days after irrigation occurred soil moisture was distributed uniformly across the bed tops at both soil depths (Fig. 3).
In contrast, 2 days after subsurface drip irrigation occurred soil moisture was significantly lower at both soil depths than under furrow irrigation. Under subsurface drip irrigation, soil moisture at a depth of $15 \mathrm{~cm}$ was significantly higher than at $5 \mathrm{~cm}$, and soil moisture progressively decreased with distance from either side of the bed center (Fig. 3).

\section{DISCUSSION}

The results from this study show that subsurface drip irrigation can be an effective nonchemical approach to managing soilborne diseases of lettuce in areas with insignificant amounts of rainfall during the lettuce crop-growing season. Lettuce drop incidence and corky root severity were lower and yield was higher under subsurface drip irrigation compared to furrow irrigation. The incidence of drop was nearly identical in both fungicide-sprayed and unsprayed lettuce plots under subsurface drip irrigation, suggesting that additional lettuce drop control benefits do not accrue from the fungicide application under subsurface drip irrigation. These differences between the two irrigation systems were caused primarily by the differential moisture distribution in the beds and not
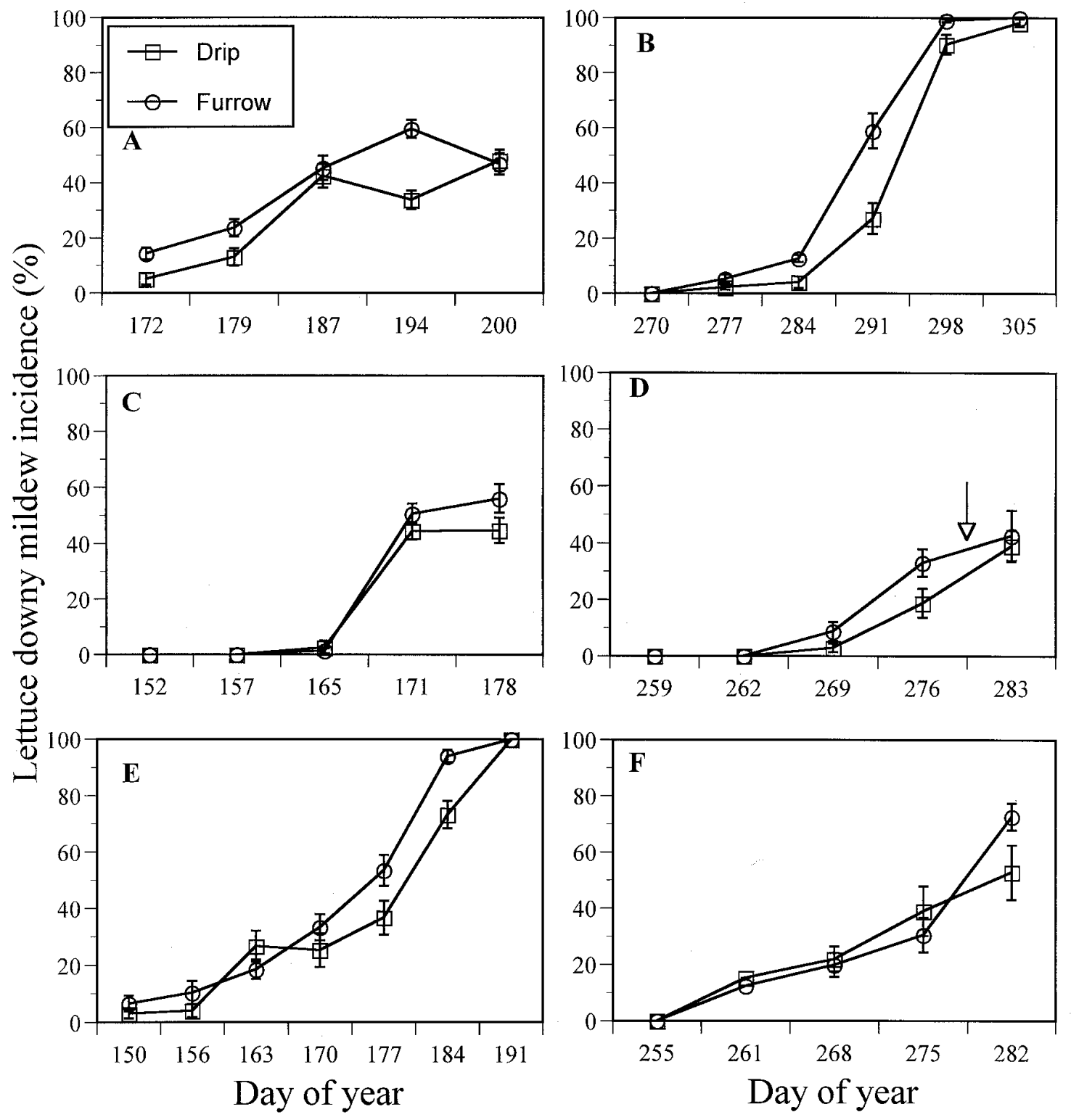

Fig. 2. Progress of lettuce downy mildew in subsurface drip- and furrow-irrigation treatments during A, C, and E, the spring and B, D, F, fall seasons of 1993 to 1995. Lettuce cvs. Salinas and Misty Day were planted during the spring and fall seasons each year, respectively. The arrow in $\mathbf{D}$ indicates the date when unseasonable rains began. Vertical bars indicate the standard errors of the mean. 
by any soil microbiological changes under the two irrigation systems (A. A. Bell, L. Liu, B. Reidy, R. M. Davis, and K. V. Subbarao, unpublished data). Plots under furrow irrigation added significantly greater numbers of sclerotia after each lettuce crop, and numbers of sclerotia increased significantly over the period of study compared with plots under drip irrigation. The degree of aggregation of sclerotia was decreased by conventional tillage under furrow irrigation; the distribution patterns and numbers of sclerotia were changed little by minimum tillage under drip irrigation. The combination of low inoculum added and its aggregated distribution by minimum tillage make subsurface drip irrigation a valuable cultural practice for lettuce drop management (K. V. Subbarao, unpublished data).

The lower soilborne disease levels on lettuce under subsurface drip irrigation may have been caused by one or a combination of the following factors. Lettuce root systems exhibit a high degree of plasticity, and irrigation methods could significantly affect the lettuce root distribution and architecture. This, in turn, may increase or decrease the competence volume of $S$. minor sclerotia and, correspondingly, increase or decrease the probability of infection by both $S$. minor and $R$. suberifaciens. Under furrow irrigation, lettuce produces roots that generally are dispersed throughout the top $50 \mathrm{~cm}$ of the beds and furrows, with more root biomass present in the 0 - to $15-\mathrm{cm}$ layer of the beds (13). In contrast, subsurface drip irrigation typically results in a smaller more confined root system than either furrow or sprinkler irrigation. The root system under subsurface drip irrigation is generally smaller, with more roots in the beds than in the furrows and a greater pro-
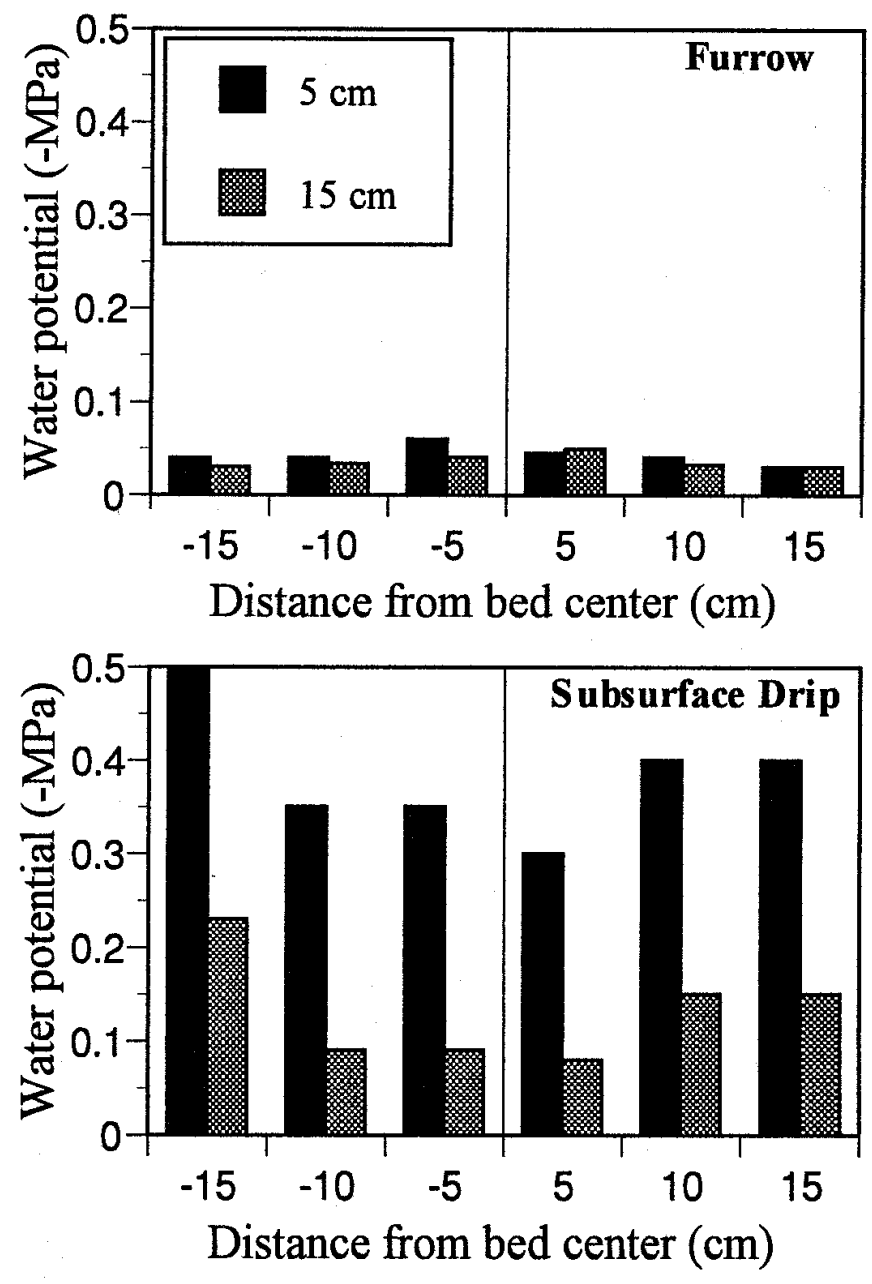

Fig. 3. Soil water potential (megapascals) at various distances on either side of the bed centers at two depths 2 days after furrow and subsurface drip irrigation. The drip tapes were located $25 \mathrm{~cm}$ below the surface of the soil. portion of roots at a depth of 0 to $15 \mathrm{~cm}$ (13). Even though the concept of competence volume (9) was developed for pathogens forming relatively large sclerotia and hosts with a well-defined taproot system, the differential root distribution under the two irrigation systems can be expected to have a significant impact on infection by $R$. suberifaciens. The propensity for greater levels of soilborne diseases, thus, are higher under furrow irrigation than under subsurface drip irrigation, and the results obtained in this study validate these hypotheses.

Sclerotia survive best under fluctuating wet and dry moisture regimes $(2,12)$, and the maximum depth from which germinated sclerotia are able to infect lettuce plants is $2 \mathrm{~cm}$ (11). Maximum germination of $S$. minor sclerotia occurs at $-0.03 \mathrm{MPa}$, and germination progressively decreases with decreasing matric potential (12). Precise moisture requirements for infection by $R$. suberifaciens are unknown, but excessive moisture around the lettuce root zone exacerbates corky root and prevents adequate root system development for efficient water and $\mathrm{N}$ uptake (23). Excessive moisture conditions seldom occur under subsurface drip irrigation because of the steady application of water from drip tapes buried 15 to $20 \mathrm{~cm}$ below the soil surface. Occasionally, the surface of planting beds above the drip tape becomes wet due to capillary action but becomes dry again within 24 to 48 h. Furthermore, soil moisture progressively decreases from the location of the drip tape and time after an irrigation event. Regardless of the depth, the maximum water potential at a depth of $5 \mathrm{~cm}$ along the lettuce seed rows under subsurface drip irrigation was approximately $-0.3 \mathrm{MPa}$ 2 days after irrigation. The soil matric potential soon approached $-1.0 \mathrm{MPa}$, which is not conducive to germination of $S$. minor sclerotia $(2,12)$. The low soil moisture at a depth of $5 \mathrm{~cm}$ throughout the bed surface under subsurface drip irrigation most likely prevented germination of sclerotia and infection of lettuce plants and perhaps reduced the chances of infection by the corky root pathogen or the subsequent progress of corky root. In contrast, the soil matric potential was about $-0.3 \mathrm{MPa} 2$ days after furrow irrigation at both 5 and $15 \mathrm{~cm}$ depths and fluctuated between -0.3 and $-0.45 \mathrm{MPa}$, providing the ideal pulsating soil moisture conditions for germination of $S$. minor sclerotia. These conditions, thus, were ideal for infection of lettuce plants by both $S$. minor and $R$. suberifaciens. Even though there were significant differences between the soil temperatures at the two depths, the differences were not specific to an irrigation type (A. A. Bell, L. Liu, B. Reidy, R. M. Davis, and K. V. Subbarao, unpublished data). The temperature differences, thus, were unlikely to have caused the observed differences in the soilborne diseases under the two irrigation systems.

The lack of significant differences in lettuce drop incidence between the fungicide-sprayed and unsprayed plots under subsurface drip irrigation and the significant differences recorded under furrow irrigation also can be explained by the differential moisture distribution under the two irrigation systems. The purpose of fungicide spraying for lettuce drop control is to create a barrier between the lettuce plants and soil surface, so mycelium from germinated $S$. minor sclerotia do not come in contact with senescent lettuce tissues. Therefore, it also is critical to spray the fungicides immediately after thinning prior to the rapid expansion of lettuce plants to create the barrier on as much soil surface as possible (16). Under furrow irrigation, spraying fungicide immediately after thinning reduced lettuce drop incidence significantly despite optimal conditions for pathogen infection of lettuce plants. Under subsurface drip irrigation, however, the lower moisture near the surface, in addition to creating less than minimal conditions for the germination of sclerotia, also may arrest the growth of mycelium toward senescent tissues. Thus, the low soil moisture under the subsurface drip irrigation itself acts as a barrier, and spraying fungicides under this irrigation system does not provide additional benefit; in fact, subsurface drip irrigation obviates the need for fungicide use, as demonstrated in this study. 
The consistently lower lettuce drop incidence under subsurface drip irrigation also translates into significantly lower augmentation of soilborne inoculum after each lettuce crop. Not only were the number of plants contributing to the inoculum lower, but inoculum production per infected plant also was significantly lower under this management practice. Under furrow irrigation, however, nearly the entire host biomass (both above- and belowground) was converted to pathogen biomass, suggesting the soilborne inoculum under this management practice could increase rapidly with repeated lettuce crops, as in the Salinas Valley. Previously, the production of sclerotia on belowground plant parts was reported either as not occurring (8) or as occurring only down to $5 \mathrm{~cm}$ below the surface of the soil $(10,11)$.

Depending on the nature of plant diseases, the yield losses caused by them could be direct or indirect. Because $S$. minor produces enzymes and acids that macerate host tissues (15), yield losses caused by this pathogen are direct and total. Because of the differential incidence of lettuce drop under the two irrigation systems, yield losses also can be expected to be directly proportional to incidence. In addition to significantly higher marketable total yields under subsurface drip irrigation, significant increases also were observed during the majority of the seasons in the proportion of marketable heads from the total and the volume and weight per head. The yield loss under furrow irrigation, therefore, is greater than a 1:1 relationship between disease incidence and number of marketable heads. In the absence of diseases, lettuce yields under different irrigation systems with identical management inputs are comparable and more often are higher under subsurface drip irrigation (20).

The lack of consistent differences in the incidence and severity of downy mildew within seasons between the two irrigation systems was not unexpected. The mesoclimate that is favorable for lettuce cultivation in the Salinas Valley also is generally favorable for downy mildew development. The differences in the microclimate factors, such as temperature, relative humidity, and leaf wetness, under the two irrigation systems were not significant (K. V. Subbarao, unpublished data) and generally were overridden by the favorable mesoclimate conditions prevalent in the Salinas Valley. Scherm and van Bruggen (21) compared the microclimate differences between subsurface drip and furrow irrigation lettuce crops in coastal California and related them to the levels of downy mildew under the two irrigation systems. They did not observe significant differences in microclimate between the two irrigation systems prior to irrigation but did observe significant differences in leaf wetness duration up to 3 days after the irrigation event. The leaf wetness duration was significantly longer under furrow irrigation. Although the downy mildew incidence under subsurface drip irrigation generally was lower, the differences were small and not significant. They (21) also concluded that microclimate modifications by the two types of irrigation are not large enough to have a significant impact on downy mildew development. However, this study was conducted on small plots that may have masked the effects of irrigation methods on the microclimate because of advection.

In summary, economic and environmental benefits would accrue by decreased cost of fungicide application and decreased use of fungicides in the lettuce production systems, respectively, under subsurface drip irrigation. The consistently lower lettuce drop incidence under the subsurface drip irrigation also translates to lower inoculum added after each crop, contributing to the long-term sustainability of subsurface drip irrigation as a disease management practice. Furthermore, the subsurface drip-irrigation system is more efficient, provides incremental and steady application of nitrogen and water, and reduces $\mathrm{NO}_{3}{ }^{-}$leaching and contamination of the groundwater supply in lettuce production areas in coastal California.

\section{ACKNOWLEDGMENTS}

This research was funded in part by the California Iceberg Lettuce Research Advisory Board and the University of California Sustainable Agriculture Research and Education Program. We thank A. Chassot, A. Gaume, T. Gonzales, R. Gutierrez, J.-J. Hao, S. Koike, A. Lewis, E. Oakes, M. Orozco, and C.-L. Xiao for assistance.

\section{LITERATURE CITED}

1. Abawi, G. S., and Grogan, R. G. 1979. Epidemiology of diseases caused by Sclerotinia species. Phytopathology 69:899-904.

2. Abawi, G. S., Grogan, R. G., and Duniway, J. M. 1985. Effect of water potential on survival of sclerotia of Sclerotinia minor in two California soils. Phytopathology 75:217-221.

3. Adams, P. B., and Ayers, W. A. 1979. Ecology of Sclerotinia species. Phytopathology 69:896-899.

4. Adams, P. B., and Fravel, D. R. 1990. Economical biological control of Sclerotinia lettuce drop by Sporidesmium sclerotivorum. Phytopathology 80:1120-1124.

5. Anonymous. 1992. Integrated pest management for cole crops and lettuce. University of California Statewide Integrated Pest Management Project, Division of Agriculture and Natural Resources, Oakland.

6. Campbell, C. L., and Madden, L. V. 1990. Introduction to Plant Disease Epidemiology. John Wiley \& Sons, Inc., New York.

7. Dillard, H. R., and Grogan, R. G. 1985. Relationship between sclerotial spatial pattern and density of Sclerotinia minor and the incidence of lettuce drop. Phytopathology 75:90-94.

8. Grogan, R. G. 1979. Sclerotinia species: Summary and comments on needed research. Phytopathology 69:908-910.

9. Grogan, R. G., Sall, M. A., and Punja, Z. K. 1980. Concepts for modeling root infection by soilborne fungi. Phytopathology 70:361-363.

10. Imolehin, E. D., and Grogan, R. G. 1980. Effect of oxygen, carbon dioxide, and ethylene on growth, sclerotial production, germination, and infection by Sclerotinia minor. Phytopathology 70:1158-1161.

11. Imolehin, E. D., and Grogan, R. G. 1980. Factors affecting survival of sclerotia, and effects of inoculum density, relative position, and distance of sclerotia from the host on infection of lettuce by Sclerotinia minor. Phytopathology 70:1162-1167.

12. Imolehin, E. D., Grogan, R. G., and Duniway, J. M. 1980. Effect of temperature and moisture tension on growth, sclerotial production, germination, and infection by Sclerotinia minor. Phytopathology 70:1153-1157.

13. Jackson, L. E., and Stivers, L. J. 1993. Root distribution of lettuce under commercial production: Implications for crop uptake of nitrogen. Biol. Agric. Hortic. 9:273-293.

14. Jarvis, W. R., and Hawthorne, B. T. 1972. Sclerotinia minor on lettuce: Progress of an epidemic. Ann. Appl. Biol. 70:207-214.

15. Lumsden, R. D. 1979. Histology and physiology of pathogenesis in plant diseases caused by Sclerotinia species. Phytopathology 69:890-896.

16. Marcum, D. B., Grogan, R. G., and Greathead, A. S. 1977. Fungicide control of lettuce drop caused by Sclerotinia sclerotiorum 'minor'. Plant Dis. Rep. 61:555-559.

17. O'Brien, R. D., and van Bruggen, A. H. C. 1992. Yield losses to iceberg lettuce due to corky root caused by Rhizomonas suberifaciens. Phytopathology 82:154-159.

18. Patterson, C. L., and Grogan, R. G. 1985. Differences in epidemiology and control of lettuce drop caused by Sclerotinia minor and S. sclerotiorum. Plant Dis. 69:766-770.

19. Patterson, C. L., and Grogan, R. G. 1988. Relationship of growth media and drying and of age of sclerotia to eruptive germination and infections by Sclerotinia minor. Plant Dis. 72:1046-1048.

20. Sammis, T. W. 1980. Comparison of sprinkler, trickle, subsurface, and furrow irrigation methods for row crops. Agron. J. 72:701-704.

21. Scherm, H., and van Bruggen, A. H. C. 1993. Comparative study of microclimate and downy mildew development in subsurface drip- and furrow-irrigated lettuce fields in California. Plant Dis. 79:620-625.

22. Scherm, H., and van Bruggen, A. H. C. 1994. Weather variables associated with infection of lettuce by downy mildew (Bremia lactucae) in coastal California. Phytopathology 84:860-865.

23. van Bruggen, A. H. C., Brown, P. R., Shennan, C., and Greathead, A. S. 1990. The effects of cover crops and fertilization with ammonium nitrate on corky root of lettuce. Plant Dis. 74:584-589.

24. van Bruggen, A. H. C., Jochimsen, K., and Brown, P. R. 1990. Rhizomonas suberifaciens, gen. nov., sp. nov., the causal agent of corky root of lettuce. Int. J. Syst. Bacteriol. 40:175-188. 